\title{
THE EFFECT OF GONADOTROPHIN ON FOLLICLE GROWTH INITIATION IN THE NEONATAL MOUSE OVARY
}

\author{
H. PETERS, A. G. BYSKOV, S. LINTERN-MOORE, M. FABER \\ AND M. ANDERSEN
}

The Finsen Laboratory, The Finsen Institute, Copenhagen, Denmark

(Received 9th April 1973)

\begin{abstract}
Summary. The injection of gonadotrophin (PMSG) into mice between the ages of 3 and 6 days did not alter the number of follicles that started growth, suggesting that it did not provide the stimulus to small follicles to start their development. The injection of PMSG had no influence on small oocyte atresia.
\end{abstract}

The growth of follicles in mice and rats can be stimulated with gonadotrophins during the late juvenile period. Injection of PMSG and HCG during the 4th week of life leads to the release of up to ten times as many eggs as in the control animal (Zarrow \& Wilson, 1961; Gates, 1971). Both FSH and LH influence follicle development (see review by Rowlands \& Parkes, 1966), but it is not yet known whether gonadotrophin can influence the initiation of follicle growth. Price \& Ortiz (1944) injected gonadotrophins into rats daily during the 1st week of life and found that the weight of the ovary increased $7 \%$ by the end of this period. No histological changes were found. The blocking of gonadotrophins with antigonadotrophins in mice during the 1st and 2nd weeks of life did not stop the initiation of follicle growth, though it disturbed the normal development of the cell layers surrounding the oocyte (Eshkol, Lunenfeld \& Peters, 1970; Eshkol \& Lunenfeld, 1972). Recently, Welschen (1973) determined the amount of gonadotrophins necessary to maintain normal follicle growth, defined by the development of follicles larger than $200 \times 10^{5} \mu \mathrm{m}^{3}$, in hypophysectomized adult rats. The possibility of the need for gonadotrophins to stimulate the follicles to start growth was not studied. The majority of germ cells are present as small follicles in the ovary and in any 24-hr period, a certain proportion of these start to grow. This number is largest in early infancy and is reduced progressively as maturity approaches (Pedersen, 1969). The stimulus for the initiation of growth is not yet known.

The purpose of this investigation was to determine whether exogenous gonadotrophin influences follicle growth initiation. To test this, twenty-two female mice from seven litters were used. The litters were mixed, i.e. shortly after birth half the number of young born to Mother A were given to Mother B who had littered on the same day, while Mother B contributed half her female offspring to Mother A. The young nursed by Mother A became the experimental 
animals while those of Mother $B$ served as controls. Eleven mice were injected subcutaneously with 1 i.u. PMSG (Antex, Leo) in $0.1 \mathrm{ml} \mathrm{NaCl}$ three times a day for 4 days between the ages of 3 and 6 days. Eleven litter mates, injected on the same time schedule with $0.1 \mathrm{ml} \mathrm{NaCl}$, served as controls. The animals were killed $2 \mathrm{hr}$ after the last injection. In the serially sectioned ovaries, the number of follicles that had started growth was determined by differential counts of follicles with more than twenty-one granulosa cells in their largest cross-section (Eshkol et al., 1970). These represent the beginning stages of follicle growth (Pedersen \& Peters, 1968). In addition, the number of small follicles was determined (Mandl \& Zuckerman, 1951). The results are summarized in

Table 1. Number of small and growing follicles in ovaries of 6-day-old mice receiving PSMG or $\mathrm{NaCl}$ injections

\begin{tabular}{|c|c|c|c|c|c|}
\hline \multirow{2}{*}{ Treatment } & \multirow{2}{*}{$\begin{array}{c}\text { Small } \\
\text { follicles }\end{array}$} & \multicolumn{3}{|c|}{ Growing follicles } & \multirow{2}{*}{$\begin{array}{c}\text { Total } \\
\text { growing } \\
\text { follicles }\end{array}$} \\
\hline & & 21 to $40^{*}$ & 41 to $60^{*}$ & $>60^{*}$ & \\
\hline $\begin{array}{l}11 \text { mice, } 1 \text { i.u. PMSG } \\
3 \text { times/day, Days } 3 \text { to } 6\end{array}$ & $4500 \pm 254$ & $85 \pm 7$ & $23 \pm 5$ & $14 \pm 5^{\text {N.s. }}$ & $121 \pm 14$ \\
\hline $\begin{array}{l}11 \text { mice, } 0.1 \mathrm{ml} \mathrm{NaCl} \\
3 \text { times/day, Days } 3 \text { to } 6\end{array}$ & $4970 \pm 203$ & $85 \pm 9$ & $22 \pm 4$ & $7 \pm 2^{\text {N.S. }}$ & $115 \pm 13$ \\
\hline
\end{tabular}

Values expressed as means \pm S.E.M. N.S., not significant.

* Number of cells in largest cross section.

Table 1. Statistical significance was determined by Student's $t$ test with a $P$ value of 0.05 or less being considered significant. A non-parametric test for analysis of variance (Hald, 1957) did not reveal any 'between litter' variation.

The total number of follicles that had started to grow did not differ in the animals injected with PMSG from those in the controls. Their number was also similar in the different developmental stages except for the largest ones, of which there seemed to be more in the treated ones than in the controls, though the difference was statistically not significant $(P>0 \cdot 25)$. The number of small follicles, i.e. those that had not started growth, was similar in the two groups (Table 1).

These results show that PMSG did not enhance the stimulus necessary for small follicles to start growth. This correlates with the finding that semispaying mice in the neonatal period did not alter the number of follicles that started growth in the remaining ovary in the subsequent 12 days (Peters \& Braathen, 1973). These observations, together with the fact that antigonadotrophins injected for 5 days during the neonatal period did not prevent follicle growth initiation (Eshkol \& Lunenfeld, 1972), suggests that although gonadotrophins are necessary for the stimulation and maintenance of the growth of large follicles, they do not stimulate the small resting follicles to start on their development. Furthermore, as PMSG did not alter the number of small follicles present in the ovary of 6-day-old mice, it seems likely that gonadotrophins have no effect on the atresia of small oocytes. 


\section{REFERENCES}

EshKol, A. \& Lunenfeld, B. (1972) Gonadotropic regulation of ovarian development in mice during infancy. In: Gonadotropins, p. 335. Eds. B. B. Saxena, C. G. Beling and H. M. Gandy. Wiley Interscience, New York and London.

Eshrol, A., Lunenfeld, B. \& Peters, H. (1970) Ovarian development in infant mice. Dependence on gonadotrophins. In: Gonadotrophins and Ovarian Development, p. 249. Eds. W. R. Butt, A. C. Crooke and M. Ryle. Livingstone, Edinburgh and London.

GATEs, A. H. (1971) Maximizing yield and developmental uniformity of eggs. In: Methods in Mammalian Embryology, p. 64. Ed. J. C. Daniel, Jr. W. H. Freeman, San Francisco.

HALD, A. (1957) Statistical theory with engineering application. John Wiley \& Son, New York.

MANDL, A. \& ZuCKerman, S. (1951) The relationship of age to number of oocytes. F. Endocr. 7, 190.

Pedersen, T. (1969) Follicle growth in the immature mouse ovary. Acta endocr., Copenh. 62, 117.

Pedersen, T. \& Peters, H. (1968) Proposal for a classification of oocytes and follicles in the mouse ovary. F. Reprod. Fert. 17, 555.

Peters, H. \& Braathen, B. (1973) The effect of unilateral ovariectomy in the neonatal mouse on follicular development. F. Endocr. 56, 85.

Price, D. \& Ortiz, E. (1944) The relation of age to reactivity in the reproductive system of the rat. Endocrinology, 34, 215.

Rowlands, I. W. \& Parkes, A. S. (1966) Hypophysectomy and the gonadotrophins. In: Marshall's Physiology of Reproduction, Vol. 3, p. 26. Ed. A. S. Parkes. Longmans, Green and Co., London.

WeLsChen, R. (1973) Amounts of gonadotrophins required for normal follicular growth in hypophysectomized adult rats. Acta endocr., Copenh. 72, 137.

Zarrow, M. X. \& Wirson, E. D. (1961) The influence of age on superovulation in the immature rat and mouse. Endocrinology, 69, 851. 